\title{
Submersible study of the East Pacific Rise
}

\section{from members of the Geocyarise expedition}

ON 5 March 1984 the French research vessel Nadir docked at Manzanillo, Mexico, at the end of a highly successful leg of diving operations on the East Pacific Rise using the submersible Cyana. Several key sites between $11^{\circ}$ and $13^{\circ} \mathrm{N}$ were explored, with the specific aim of studying hydrothermal processes.

Previous investigations by French vessels had established, near $12^{\circ} 50^{\prime} \mathrm{N}$, the existence of a narrow zone (less than $200 \mathrm{~m}$ wide and $20 \mathrm{~km}$ long) of intense hydrothermal activity believed to be due to the presence of a shallow magma reservoir beneath the axis. The East Pacific Rise in this vicinity is conspicuously asymmetric, with off-axis seamounts on one side and linear normal faults on the other. Geological reconnaissances were carried out on four seamounts located $4 \mathrm{~km}$ west of the rise axis near $11^{\circ} 30^{\prime} \mathrm{N}(\mathrm{A}), 18 \mathrm{~km}$ west of the axis at $12^{\circ} 38^{\prime} \mathrm{N}(\mathrm{B}), 6 \mathrm{~km}$ east of the axis at $12^{\circ} 43^{\prime} \mathrm{N}(\mathrm{C})$ and $6 \mathrm{~km}$ east of the axis at $12^{\circ} 50^{\prime} \mathrm{N}(\mathrm{D})$.

Seamounts $\mathrm{A}$ and $\mathrm{C}$, which are structurally similar and rise less than $400 \mathrm{~m}$ above the surrounding sea floor at $2,700 \mathrm{~m}$, were explored extensively. Linear north-south aprons some $500 \mathrm{~m}$ long and less than $100 \mathrm{~m}$ in relief extend south from the eastern and western margins of both seamounts. Extensive hydrothermal deposits found on seamount C during a Cyana dive in 1982. On this leg, highly-altered fragile hydrothermal edifices several metres high were found around an apron of seamount

\section{0 years ago}

\section{THE PRIME MERIDIAN CONFERENCE}

THE Prime Meridian Conference at Washington on Monday adopted the Greenwich line as the universal prime meridian. Only one vote - that of St. Domingo - was given against its adoption; but the representatives of France and Brazil declined to vote.

To the American resolution for adopting the Greenwich line, Mr. Fleming (Canada) moved an amendment to the effect that the Conference should adopt the 180th degree of longitude east from Greenwich as the prime meridian; but the other British delegates opposing the proposition, it was lost. M. Lefaivre (France) said the Greenwich was not a scientific meridian, and that it implied no progress in any science, but was merely a commercial standard. Since, therefore, nothing would be gained to science by adopting Greenwich, France could not make a sacrifice of her own meridian, and incur the vast expense consequent upon the adoption of a new one, because she would thereby gain no advantage whatever. Sir William Thomson said that it was purely a matter of convenience, and that Greenwich answered the world's convenience better than any other standard meridian. From Nature 30, 603, 16 October 1884.
A. Its western flank consisted of a vertical fault scarp with extensive piles of talus at its foot composed of sulphide boulders and fragments of massive flows. Extensive areas of $\mathrm{Fe}$ oxides, hydroxides and thick $(>2 \mathrm{~cm}) \mathrm{Fe}-\mathrm{Mn}$ crusts were encountered during dives from the southern foot of the seamount to its top.

Three dives confirmed the existence of a massive sulphide field capped with ochreous oxidation products on the western limb of an apron of seamount $C$. Hydrothermal material extends at least $800 \mathrm{~m}$ down the south flank of the seamount from its top and some $500 \mathrm{~m}$ in an east-west direction along the $2,600 \mathrm{~m}$ isobath. Assuming the deposit to be, on average, $3 \mathrm{~m}$ thick and to have a density of $3.0 \mathrm{~g} \mathrm{~cm}^{-3}$, its mass is conservatively estimated to be more than $2 \times 10^{6}$ tonnes. Metal contents in the deposit are in the range $20-40$ per cent $\mathrm{Fe}, 1-3$ per cent $\mathrm{Cu}$ and less than 1 per cent Co. This deposit differs from those on the adjacent Rise axis in its massive appearance, its relative depletion in zinc sulphide and its abundance of hydrated silica. The smaller size ( $<50 \mathrm{~m}$ diameter) and richer metal ( $\mathrm{Cu}$ and $\mathrm{Zn}$ ) content of the Rise axis deposits suggest a faster deposition at a higher temperature than occurred for the seamount deposit. The age of the deposit on seamount $C$ is unknown, although the lack of sediment cover indicates a relatively recent origin. The crust on which the seamount lies is approximately 100,000 years old. The occurrence of fresh pillow flows partially covering some of the ochreous hydrothermal products indicates off-axis volcanic activity. Interestingly, near the base of the seamounts at 2,700 m depth the pillow flows are almost entirely covered by pelagic sediment.

A semicircular volcanic structure located between seamount $\mathrm{C}$ and the rise.axis showed evidence of recent off-axis hydrothermal activity. A diffuse white fluid was exiting from hydrothermal edifices on top of a volcanic peak ( $<50 \mathrm{~m}$ in height) made up of fresh sheet flows, and a large amount of ochreous sediment with slumped boulders of massive sulphide was observed at its base.

Two dives took place on the eastern margin of the axial graben near $12^{\circ} 50^{\prime} \mathrm{N}$ in order to study the alteration and mode of emplacement of sulphide precipitates at recently active hydrothermal sites. A field of green-coloured altered pillows and flows mixed with sulphide boulders, which formed piles of talus at the foot of a $30 \mathrm{~m}$ high fault scarp, was observed. Along the wall was an extensive stockwork of sul- phide filled veins ( $<50 \mathrm{~m}$ wide) within altered country rock containing chloritesmectite-sulphide assemblages typical of low-grade metamorphism.

The of fset spreading centre discovered by Macdonald and Fox (Nature 301, 55; 1983) at $12^{\circ} 53^{\prime} \mathrm{N}$ was the target for another dive. The eastern segment seemed relatively old, with flows and pillows partially covered by sediment. The western ridge is marked by a small graben (some 10 m deep and $30 \mathrm{~m}$ wide) containing fresh lobated flows but discontinuous along the axis. The sporadic occurrence of Galathea and brachyuran crabs indicated hydrothermal activity nearby. Proceeding northwards along the western axis the basaltic flows become fresher in appearance (very shiny glassy surfaces) and ochreous sediments more common, suggesting increasing hydrothermal activity. By contrast, the eastern ridge at the same latitude is apparently inactive and being tectonically disrupted.

The first electrical resistivity measurements of the seabed to be made from a submersible were carried out by T.J.G. Francis of the Institute of Oceanographic Sciences, UK. At each site an electrical cable $50 \mathrm{~m}$ long was laid along the bottom. Current was passed between electrodes $30 \mathrm{~m}$ apart by means of a $12 \mathrm{~V}$ battery within the submersible and voltages were detected by $\mathrm{Ag}-\mathrm{AgCl}$ potential electrodes. The resistivity of the pillow lava terrain was about 40 times that of seawater, in good agreement with downhole logging measurements in DSDP drill holes. The resistivity of the sulphide deposit was between one and two orders of magnitude less than that of the pillow basalts. At one site the seabed was approximately twice as conductive as the seawater and preliminary measurements suggest the sulphides could be of the order of $15 \mathrm{~m}$ thick. Self potentials were observed associated with the sulphide deposit.

Electrical potentials were also measured in the water column in order to determine whether hydrothermal fluids exiting from the seabed create masses of water with a different (redox) potential from the adjacent water mass. This experiment, devised by $\mathrm{F}$. Avedik of CNEXO-COB, consisted of measuring the potential difference between one non-polarizing electrode held at $150 \mathrm{~m}$ depth and another lowered to the ocean floor at a depth of $2,600-2,900 \mathrm{~m}$. Negative anomalies with amplitudes of 6-8 mV were observed next to the sea floor, some of which extended up to $500-600 \mathrm{~m}$ above the bottom. This type of measurement could prove to be a useful way of detecting the presence of hydrothermal activity.

Contributors to this article were R. Hekinian, $F$. Avedik, $D$. Bideau and $Y$. Fouquet from the Centre Océanologique de Bretagne, Brest, France; T.J.G. Francis of the Institute of Oceanographic Sciences, Wormley, Surrey, UK; J.M. Franklin of the Geological Survey of Canada, Ottawa, and W.D. Nesteroff of the Université Pierre et Marie Curie, Paris. 